\title{
Childhood Obesity - challenges in the Indian Scenario
}

\author{
DS Gedam ${ }^{1}$ \\ ${ }^{1}$ Dr. D Sharad Gedam, MBBS, MD, Editor- in- chief, IJMRR \\ Address for correspondence: Dr. D Sharad Gedam, Email: editor.ijmrr@gmail.com
}

\begin{abstract}
Globally, a sharp rise in the incidence of obesity has been noticed in last three decades. It has not only involved developed countries but also low income group developing countries.
\end{abstract}

Key words: Obesity, adolescent, global scenario

\section{Introduction}

Of late, obesity has been increasing at an alarming rate among all age groups. The International Obesity Task Force (IOTF); World Health Organization (WHO) estimate of the prevalence of overweight (including obesity) among children aged 5-17 years is 10\%. Developing countries like India are facing the peculiar situation of having to deal with both ends of the spectrum of nutritional disorders.

On one hand, mal (under)nutrition is an epidemic which has been in vogue for ages. In India, still around 46 per cent of all children below the age of three are too small for their age, 47 per cent are underweight and at least 16 per cent are wasted. Many of these children are severely malnourished[1].

On the other hand, over nutrition evident as overweight and obesity has been recently on the rise and is present in $20.6 \%$ of boys and $18.3 \%$ of girls [2]. In children, obesity is the most common nutritional disease in developed countries and in affluent class of developing countries. Obesity is a condition of excess body fat. There is no consensus definition for obesity. Weight alone is not a good indicator.

The most acceptable definition was given by IOTF/ WHO in terms of Body mass index (BMI) [3,4]. BMI is calculated by dividing weight in kilograms by the square of height in meters. BMI between 18.5 and 25 is normal and between 25(85th percentile) and 30(95th percentile) is overweight. Obesity is defined as BMI more than 30. In spite of the fact that BMI has drawbacks in the form of inability to differentiate between muscle and fat mass, it is advocated by most. BMI is also considered best for community based studies owing to the ease of its use, without much expenditure [5]. Population specific BMI criteria for the Indian population are desirable, but are unavailable in India at present. WHO/IOTF cut offs need to be followed for population based studies till the time we develop such criteria.

\section{The global scenario}

Globally, a sharp rise in the incidence of obesity has been noticed in last three decades. It has not only involved developed countries but also low income group developing countries. In developed countries like United States of America, the incidence is $35 \%$ in boys and $35.9 \%$ in girls ${ }^{1}$. Similarly in UK it is $21.8 \%$ and $26.1 \%$ in boys and girls respectively.

In the Middle East, highest incidence is seen in UAE where one in five children is having either over weight/obesity. In a recent review from developed countries, prevalence of overweight youth was $>15 \%$ in North America (Canada, Mexico and USA) and European countries (Germany, Italy) and $5-15 \%$ in France and Sweden. In China, overweight children account for 4.5 and $5.9 \%$ of boys and girls respectively.

Among African countries, prevalence is between $10-20 \%$ in South Africa and Nigeria [1].

In developing countries like Brazil (23.1 \& 21.1\%) and Chile $(28.6 \& 27.1 \%)$ also, prevalence is very high.

Available online at: $\underline{\text { www.ijmrr.in }}$ 1 | P a g e 
Editorial

\section{The Indian scenario}

Various studies over the last decades in India have shown that there is an increase in prevalence of overweight and obesity (Table 1). In a meta analysis of nine studies in which 92,862 subjects were identified and analysed, the prevalence of overweight was estimated to be $12.64 \%$ (95\% CI 8.48 $16.80 \%)$ and that of obesity to be $3.39 \%$ (95\% CI 2.58 $4.21 \%)$.

Table 1: Prevalence of Overweight/Obesity in Indian Studies.

\begin{tabular}{|c|c|c|c|c|c|}
\hline No & Author(s) & Age Group & $\begin{array}{l}\text { Total No. } \\
\text { student }\end{array}$ & Location & Prevalence \\
\hline 1. & $\begin{array}{l}\text { Deoke et al [6] } \\
(2012)\end{array}$ & $5-17$ & 565 & Nagpur & $\begin{array}{l}\text { Overweight- } 5.84 \% \\
\text { Obesity- } 0.35 \%\end{array}$ \\
\hline 2. & $\begin{array}{l}\text { Misra et al [7] } \\
(2011)\end{array}$ & $8-18$ years & 29,244 & $\begin{array}{l}\text { Multicentric } \\
\text { (India) }\end{array}$ & $\begin{array}{l}\text { IOTF: Overweight- } 14.4 \% \\
\text { Obesity- } 2.8 \% \\
\text { WHO: Overweight- } 18.5 \% \\
\text { Obesity- } 5.3 \%\end{array}$ \\
\hline 3. & $\begin{array}{l}\text { Mahajan et al }[8] \\
(2011)\end{array}$ & $6-12$ years & 12,685 & Puducherry & $\begin{array}{l}\text { CDC: Overweight- } 4.41 \% \\
\text { Obesity- } 2.21 \% \\
\text { Boys: Overweight- } 4.24 \% \\
\text { Obesity- } 1.97 \% \\
\text { Girls: Overweight- } 4.58 \% \\
\text { Obesity- } 2.29 \%\end{array}$ \\
\hline 4. & $\begin{array}{l}\text { Vohra R et al [9] } \\
\text { (2011) }\end{array}$ & $10-18$ years & 407 & Lucknow & $\begin{array}{l}\text { WHO: Overweight- } 4.17 \% \\
\text { Obesity- } 0.73 \%\end{array}$ \\
\hline 5. & $\begin{array}{l}\text { Chakroborty et } \\
\mathrm{Al}[10](2011)\end{array}$ & 5-18 years & 979 & Kolkata & $\begin{array}{l}\text { Overweight- } 5.43 \% \\
\text { Obesity- } 0.56 \%\end{array}$ \\
\hline 6. & $\begin{array}{l}\text { Jain S et.al [11] } \\
(2010)\end{array}$ & $12-18$ years & 2785 & Meerut & $\begin{array}{l}\text { Boys: Overweight- } 18.36 \% \\
\text { Obesity- } 10.82 \% \\
\text { Girls: Overweight- } 19.7 \% \\
\text { Obesity- } 5.3 \%\end{array}$ \\
\hline 7. & $\begin{array}{l}\text { Premnath M et } \\
\text { Al [12] (2010) }\end{array}$ & $\begin{array}{l}5-16 \\
\text { years }\end{array}$ & 43,152 & Mysore & $\begin{array}{l}\text { IAP: Overweight- } 8.5 \% \\
\text { Obesity- } 3.4 \%\end{array}$ \\
\hline 8. & $\begin{array}{l}\text { Kumar HN et } \\
\text { Al [13] (2008) }\end{array}$ & $\begin{array}{l}2-5 \\
\text { years }\end{array}$ & 425 & Manglore & $\begin{array}{l}\text { WHO: Overweight- } 4.5 \% \\
\text { Obesity- } 1.4 \%\end{array}$ \\
\hline 9. & $\begin{array}{l}\text { Rebecca } \\
\text { Kurian et al [14] } \\
(2007)\end{array}$ & $\begin{array}{l}6-16 \\
\text { years }\end{array}$ & 598 & Banglore & IOTF: Overweight $6.4 \%$ \\
\hline 10. & $\begin{array}{l}\text { Subramanium } \\
\text { et al [15] (2003) }\end{array}$ & $10-15$ years & $\begin{array}{l}707(1991) \\
610(1998)\end{array}$ & Chennai & $\begin{array}{l}\text { 1991:Overweight-9.62 \% } \\
\text { Obesity- } 5.94 \% \\
\text { 1998: Overweight- } 9.67 \% \\
\text { Obesity- } 6.23 \%\end{array}$ \\
\hline 11. & $\begin{array}{lll}\text { Sharma } & \text { et } & \text { al } \\
{[16](2007)} & & \end{array}$ & 4-17 years & 4000 & Delhi & $\begin{array}{l}\text { Overweight- } 22 \% \\
\text { Obesity- } 6 \%\end{array}$ \\
\hline 12. & $\begin{array}{l}\text { Bose K, et al [17] } \\
(2007)\end{array}$ & 6-9 years & 431 & Kolkata & $\begin{array}{l}\text { Overweight- } 17.63 \% \\
\text { Obesity- } 6 \%\end{array}$ \\
\hline 13. & $\begin{array}{l}\text { Ramchandran } \\
\text { A, et al [18]. } \\
(2002)\end{array}$ & 13-18 years & 2382 & India & $\begin{array}{l}\text { Overweight- } \\
\text { Boys- } 17.8 \% \\
\text { Girls- } 15.8 \%\end{array}$ \\
\hline
\end{tabular}




\section{Editorial}

Important determinants of childhood obesity include high socioeconomic status, urbanisation, female gender, unawareness and false beliefs about nutrition, marketing by transnational food companies, increasing academic stress, and poor facilities for physical activity. Obesity has far reaching consequences and is associated with type 2 diabetes mellitus, the early-onset metabolic syndrome, subclinical inflammation, dyslipidemia, coronary artery diseases, and adulthood obesity. Cardiovascular diseases-coronary artery disease and stroke -are the largest cause of deaths in India currently. Obesity has played an important role in increasing the number of patients with cardiovascular diseases [19]. Undeniably, the seeds are sown much early, in childhood.

India spends lesser amount of GDP for health care compared to most other countries. There is obvious lack of a focused policy towards non communicable diseases including obesity. Equipping the Indian healthcare system to deal with prevention and management of obesity along with other agendas is a Herculean task.

Considering the consequences of this epidemic, most importantly the increasing numbers of cardiovascular diseases, spreading word about and curbing this menace merits priority. Understandably, policy changes at the government level can take us a long way forward in this journey, and there is scientific evidence to support this [20,21].

There is an urgent need of increasing awareness about and sensitizing the policy makers, healthcare personnel and the community at large to the huge burden of dual malnutrition i.e. under nutrition and over nutrition that we are facing.

\section{References}

1.Indian children. Availab le from: http://www.unicef.org/india/children_2356 .htm. Accessed on 25th January, 2013.

2. International Association for the study of obesity. World map of obesity. Available from: http://www.iaso.org/ resources/world-mapobesity/? map=children. Accessed on 25th January, 2013.

3. Cole Tim J, Bellizzi Mary C, Flegal Katherine M, Dietz William $\mathrm{H}$. Establishing a standard definition for child overweight and obesity worldwide: international survey. BMJ. 2000; 320:1240. IOTF Childhood Obesity Working group.

4. Deurenberg P, Weststrate JA, Seidell JC. Body mass index as a measure of body fatness: age- and sex-specific prediction formulas. Br J Nutr. 1991 Mar;65(2):105-14. [PubMed]

5. Midha T, Nath B, Kumari R, Rao YK, Pandey U. Childhood obesity in India: a meta-analysis. Indian $\mathrm{J}$ Pediatr. 2012 Jul;79(7):945-8. doi: 10.1007/s12098-0110587-6. Epub 2011 Oct 15. [PubMed]

6. Deoke A, Hajare S, Saoji A. Prevalence of overweight in high school students with special reference to cardiovascular efficiency. Glob J Health Sci. 2012 Feb 29;4(2):147-52. doi: 10.5539/gjhs.v4n2p147. [PubMed]
7. Misra A, Shah P, Goel K, Hazra DK, Gupta R, Seth P, Tallikoti P, Mohan I, Bhargava R, Bajaj S, Madan J, Gulati S, Bhardwaj S, Sharma R, Gupta N, Pandey RM. The high burden of obesity and abdominal obesity in urban Indian schoolchildren: a multicentric study of 38,296 children. Ann Nutr Metab. 2011;58(3):203-11. doi: 10.1159/000329431. Epub 2011 Jul 14. [PubMed]

8. Mahajan P, Purty JA, Singh Z et al. Study of Childhood Obesity Among School Children Aged 6 to 12 Years in Union Territory of Puducherry. Indian J Community Med. 2011; 36(1): 45-50.

9. Vohra R, Bhardwaj P, Srivastava JP, Srivastava S, Vohra A. Overweight and obesity among school-going children of Lucknow city. J Family Community Med. 2011 May;18(2):59-62. doi: 10.4103/2230-8229.83369. [PubMed]

10. Chakraborty P, Dey S, Pal R, Kar S, Zaman FA, Pal S. Obesity in Kolkata children: Magnitude in relationship to hypertension. J Nat Sci Biol Med. 2011 Jan;2(1):101-6. doi: 10.4103/0976-9668.82310.

[PubMed]

11. Jain S, Pant B, Chopra H, Tiwari R. Obesity among adolescents of affluent public schools in Me erut. Indian J Public Health. 2010 Jul-Sep;54(3):158-60. doi: 10.4103/0019-557X.75740. [PubMed] 


\section{Editorial}

12.Premanath M, Basavanagowdappa H, Shekar MA, Vikram SB, Narayanappa D. Mysore childhood obesity study. Indian Pediatr. 2010 Feb;47(2):171-3. Epub 2009 Apr 15. [PubMed]

13. Kumar HN, Mohanan P, Kotian S, Sajjan BS, Kumar SG. Prevalence of overweight and obesity among preschool children in semi urban South India. Indian Pediatr. 2008 Jun;45(6):497-49. [PubMed]

14. Kuriyan R, Bhat S, Thomas T, Vaz M, Kurpad AV. Television viewing and sleep are associated with overweight among urban and semi-urban South Indian children. Nutr J. 2007 Sep 20;6:25. [PubMed]

15. Subramanyam V, Jayashree R, Rafi M. Prevalence of Overweight and Obesity in Affluent Adolescent Girls in Chennai in 1981 and 1998. Indian Pediatr. 2003; 40:332-336

16. Sharma A, Sharma K, Mathur KP. Growth pattern and prevalence of obesity in affluent schoolchildren of Delhi. Public Health Nutr. 2007 May;10(5):485-91. [PubMed]
17. Bose K, Bisai S, Mukhopadhyay A, Bhadra M. Overweight and obesity among affluent Bengalee schoolgirls of Lake Town, Kolkata, India. Matern Child Nutr. 2007 Apr;3(2):141-5. [PubMed]

18. Ramachandran A, Snehalatha C, Vinitha R, Thayyil M, Kumar CK, Sheeba L, Joseph S, Vijay V. Prevalence of overweight in urban Indian adolescent school children. Diabetes Res Clin Pract. 2002 Sep;57(3):185-90. [PubMed]

19. Registrar General of India and Million Death Study Investigators: Final Report on Causes of Death in India 20012003. New Delhi, Registrar General of India; 2009.

20. Reddy KS, Shah B, Varghese C, Ramadoss A: Responding to the threat of chronic diseases in India. Lancet 2005,336:1744-49. [PubMed]

21. Leupker RV: Decline in incident coronary heart disease. Why are rates falling? Circulation 2008, 117:592-93. [PubMed]

\section{How to cite this article?}

Gedam DS. Childhood Obesity - challenges in the Indian Scenario. Int J Med Res Rev 2013;1(1):01-04. doi:

10.17511/ijmrr.2013.i01.01. 